\title{
RELATIVE ABUNDANCE OF BIRDS DURING THE BREEDING SEASON IN SASKATOON, SASKATCHEWAN
}

NAVJOT S. SODHI, Department of Zoology, University of Alberta, Edmonton, Alberta. T6G 2E9

The surveys of urban areas have revealed that such habitats support a high diversity of breeding birds. ${ }^{2,5,6,11,12,13,14,15}$ It has been suggested that urban areas can provide refuges for the native birds whose habitats have been reduced. ${ }^{9} \mathrm{Re}$ cently, bird assemblages of urban and nearby unaltered habitats have been compared to determine the extent of permeability of the urban habitats for nearby native birds. ${ }^{1,3,4,7,8}$ Surveys of urban birds, therefore, may be useful in assessing the impact of human settlement on the native bird fauna or as a base line for long-term changes in bird populations. However, relatively little is known about the structure of $\mathrm{Ca}$ -

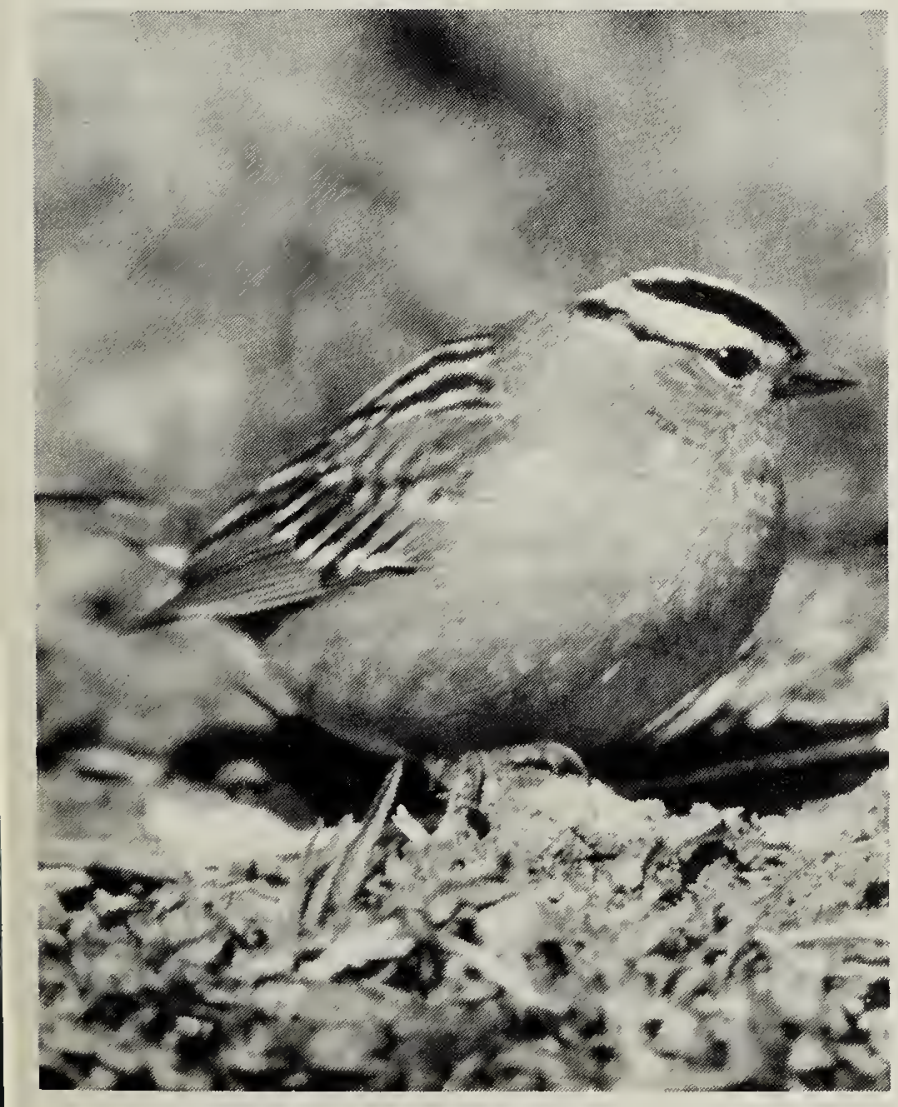

White-crowned Sparrow Wayne Lynch nadian urban bird communities. This paper presents a relative abundance of birds, estimated by point counts made at various localities in Saskatoon $\left(52^{\circ} 07^{\prime} \mathrm{N}, 106^{\circ} 38^{\prime} \mathrm{W}\right)$ during a study of predator-prey relationships of nesting Merlins.

Surveys were made almost every day between 11 May and 30 July 1987. A total of 264 was made -88 each month at stations located 0,50 , 250 , and $450 \mathrm{~m}$ from each of 11 Merlin nests. Within constraints of availability of alleys and roads, stations were randomly selected with a new selection for each count day. Whenever possible, different stations were used for subsequent counts

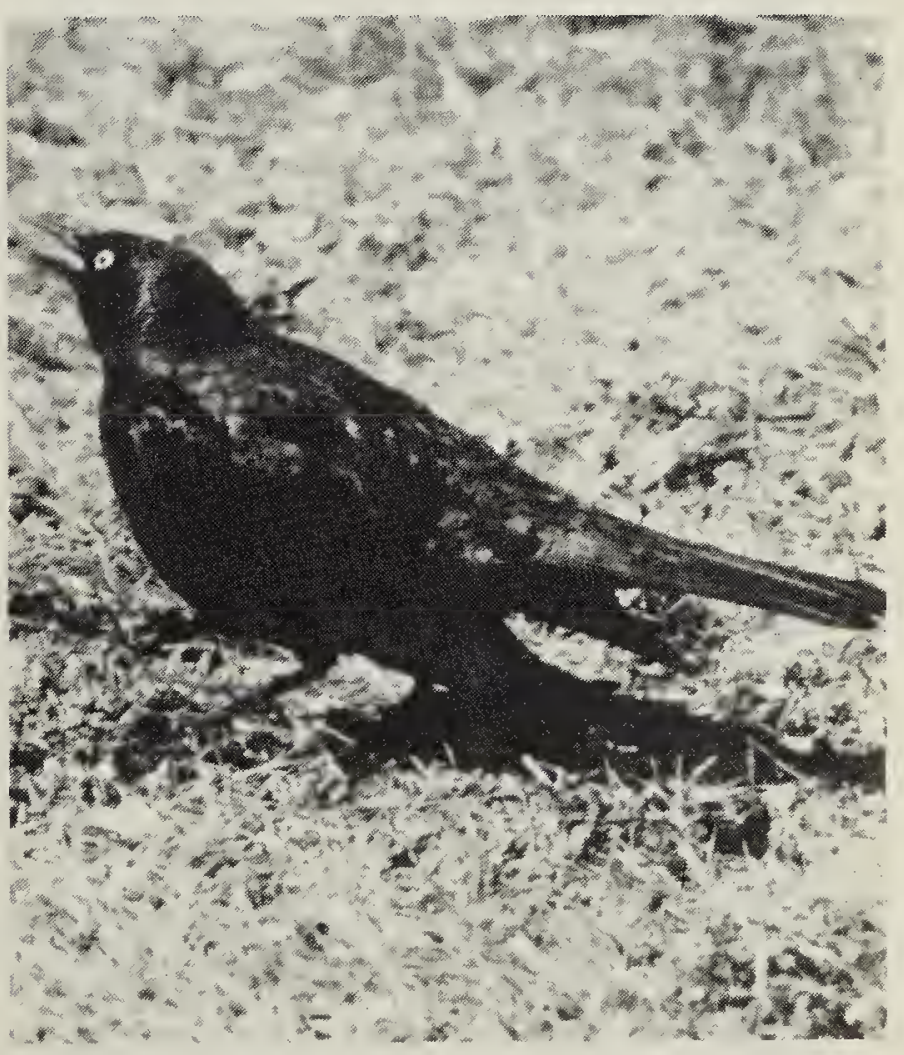

Brewer's Blackbird,

Canmore, Alberta

G.L. Holroyd 


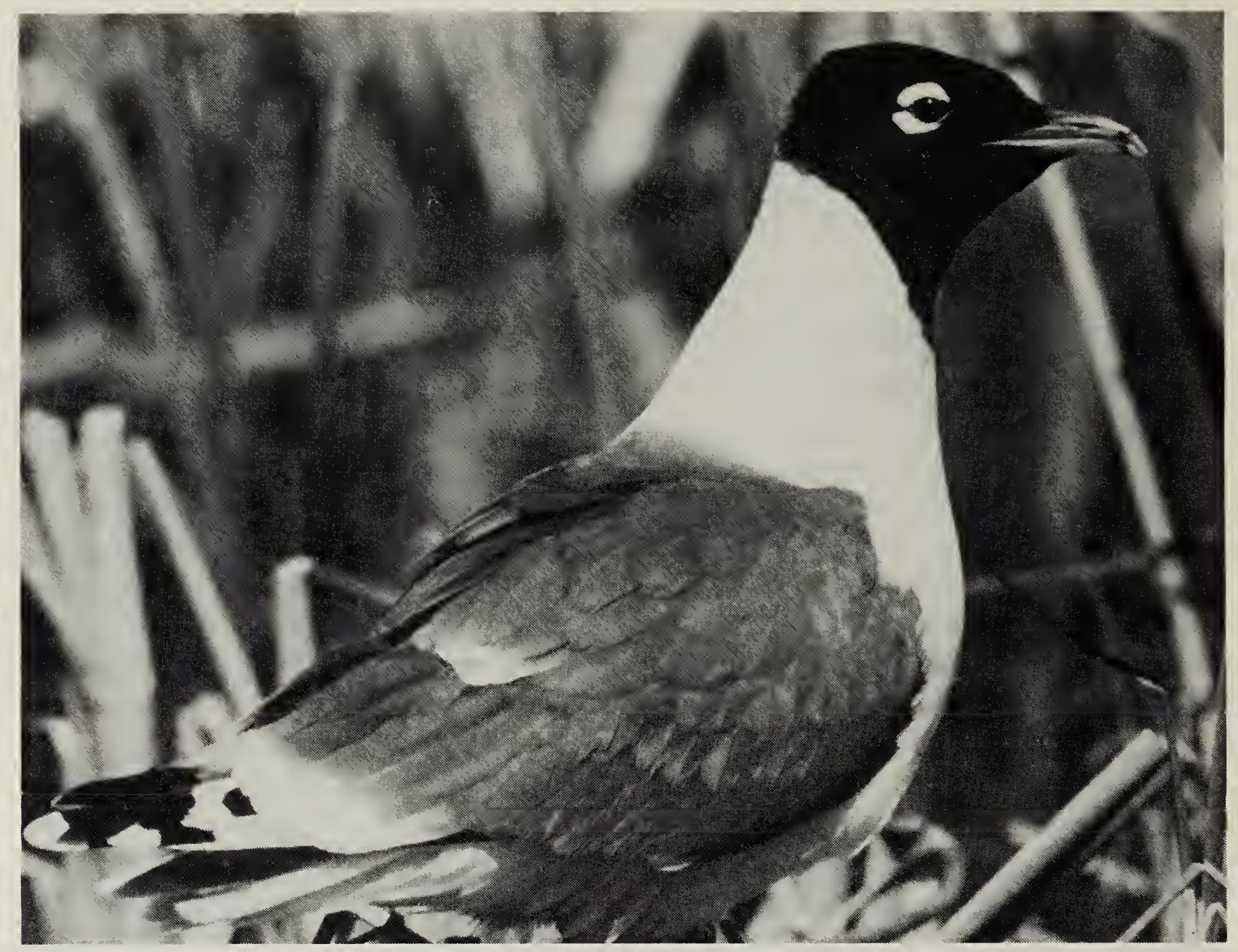

Franklin's Gull

Fred Lahrman

near a nest. All birds, seen or heard during seven minutes, were counted within $25 \mathrm{~m}$ of each point (or station). No bird was knowingly counted twice. Censuses were made only in fair weather and in the first four hours of daylight. The impact of nesting Merlins on bird abundance and detailed methods are presented elsewhere. $^{10}$ I arbitrarily classified birds that formed $6 \%$ of the total as common, $1-5 \%$ as uncommon, and < $1 \%$ as rare.

The locations of the 11 nests are given in Table 1. Two to three were surveyed during each sampling day. Each nest was visited twice during a month. It took me about 50 minutes to survey the area around a nest. The present survey recorded 36 species (Table 2). The four most common species were: House Sparrow, Chipping Sparrow, Rock Dove, and American Robin. These species formed approximately $64 \%$ of the to- tal avifauna. Of the rest, 11 were uncommon and 21 were rare species.

I found a significant correlation between relative abundance and frequency of occurrence of the 20 most common birds $\left(r_{s}=0.998, p<\right.$ 0.05). This suggests that species that were more common were more widely distributed within the city.

Two common points have emerged from quantitative studies on the urban bird communities from different locales around the world, including the present study. First, the House Sparrow was the most common species in all the surveyed cities, e.g., Tucson (USA), 1,9 Tornio (Finland), and Legnica (Poland). ${ }^{11}$ Secondly, three or four species formed the majority of recorded individuals.

Many studies have noted an increase both in bird abundance and 


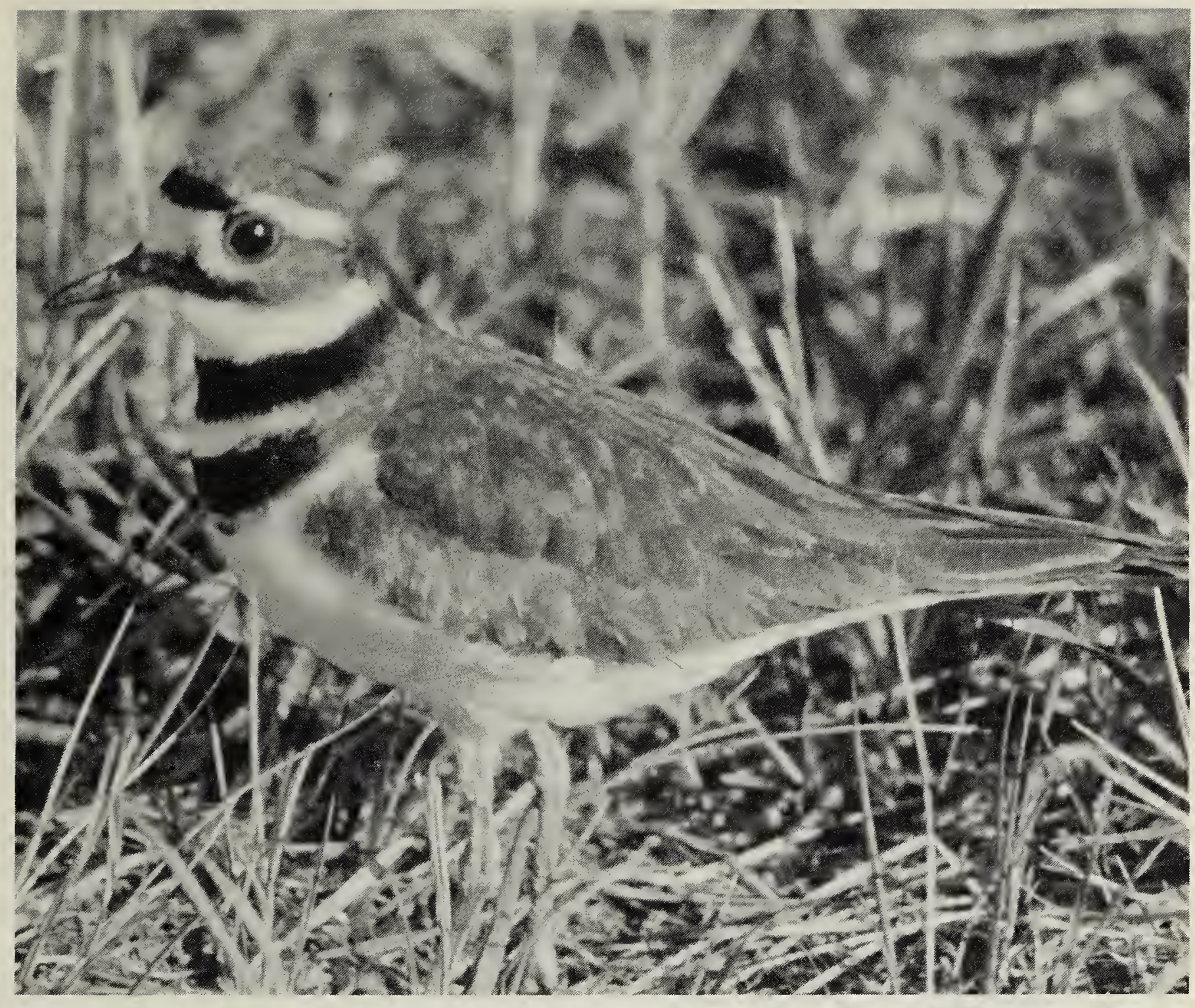

\section{Killdeer at Condie}

diversity with age of neighbourhoods in the surveyed cities. $4,5,6,7,13$ As planted shrubs and trees grow, they attract more birds. Based on year of development of neighbourhoods, Saskatoon can be broadly divided into three age categories, i.e., less than 27 years (before 1960), 27-41 (1960-1946), and more than 41 (4266 years; before 1946) years. I did not make bird counts in the neighbourhoods that were less than 27 years old, and 24 counts made on
Gary W. Seib

the outer limits of the city could not be assigned to any age category. However, 120 bird counts were made, respectively, in the neighbourhoods that were between 27-41 and more than 41 years of age. I did not find a significant difference in either mean number of species $(t=0.33$, $d f$ $=238, p>0.05)$ or individuals $(t=$ 0.85 , df $=238, p>0.05$ ) recorded in these two neighbourhoods (Table 3 ). It is possible that both bird abundance and diversity increase up to a

\section{Table 1. LOCATIONS OF 11 MERLIN NESTS IN SASKATOON WHERE POINT COUNTS WERE MADE.}

1705 Munroe Avenue 1406 14th Street East

719 8th Avenue North

City Parks and Recreation

(Avenue $P$ and 31 st Street)

700 Avenue H North

President's Residence

(Elliot Avenue and College Drive)
School for the Deaf (Cumberland Avenue and Osler Street)

Buena Vista Park

Simpkins (north side;

NW of Preston Avenue and Circle Drive)

110112 th Street

Central Avenue and 117th Street 


\section{Table 2. RELATIVE ABUNDANCE, FREQUENCY OF OCCURRENCE, AND STATUS OF BIRDS REVEALED BY COUNTS MADE AT 44 POINTS IN SASKATOON BETWEEN 11 MAY AND 30 JULY 1987.}

Relative abundance is number of birds of a given species detected $\times 100 /$ Total number of detections of all species; and frequency of occurrence is the number of counts in which a given species was present $x 100$ /total number of counts.

$\mathrm{C}=$ common, $\mathrm{U}=$ uncommon, and $\mathrm{R}=$ rare birds. $+=$ values less than $0.5 \%$.

\begin{tabular}{|c|c|c|c|}
\hline Species & $\begin{array}{c}\text { Relative } \\
\text { Abundance }^{*}\end{array}$ & $\begin{array}{l}\text { Frequency of } \\
\text { Occurrence }\end{array}$ & Status \\
\hline House Sparrow & 34.5 & 80.7 & $\mathrm{C}$ \\
\hline Chipping Sparrow & 13.7 & 79.1 & $\mathrm{C}$ \\
\hline Rock Dove & 8.1 & 26.5 & C \\
\hline American Robin & 7.9 & 47.3 & $\mathrm{C}$ \\
\hline American Crow & 4.8 & 33.7 & u \\
\hline Brewer's Blackbird & 4.3 & 24.2 & $\mathrm{U}$ \\
\hline Cedar Waxwing & 4.1 & 21.9 & $U$ \\
\hline Black-billed Magpie & 3.4 & 25.3 & $\underline{U}$ \\
\hline Ring-billed Gull & 3.0 & 27.6 & $U$ \\
\hline Clay-colored Sparrow & 2.9 & 27.2 & $\mathrm{U}$ \\
\hline Yellow Warbler & 2.1 & 19.7 & $\mathrm{U}$ \\
\hline European Starling & 1.7 & 4.2 & $\mathrm{U}$ \\
\hline Merlin & 1.6 & 15.1 & U \\
\hline Franklin's Gull & 1.3 & 7.6 & $U$ \\
\hline House Wren & 1.2 & 14.8 & $\mathrm{U}$ \\
\hline Western Kingbird & 0.9 & 4.9 & R \\
\hline Western Meadowlark & 0.9 & 8.3 & $\mathrm{R}$ \\
\hline Black-capped Chickadee & 0.6 & 6.1 & $\mathrm{R}$ \\
\hline Common Grackle & 0.5 & 4.9 & $\mathrm{R}$ \\
\hline Tree Swallow & 0.5 & 1.5 & $\mathrm{R}$ \\
\hline American Goldfinch & + & 3.8 & $\mathrm{R}$ \\
\hline Red-eyed Vireo & + & 2.6 & $\mathrm{R}$ \\
\hline American White Pelican & + & 1.3 & $\mathrm{R}$ \\
\hline American Kestrel & + & 1.9 & $\mathrm{R}$ \\
\hline Killdeer & + & 1.1 & $\mathrm{R}$ \\
\hline White-throated Sparrow & + & 2.3 & $\mathrm{R}$ \\
\hline California Gull & + & 0.8 & $\mathrm{R}$ \\
\hline Horned Lark & + & + & $\mathrm{R}$ \\
\hline White-crowned Sparrow & + & 0.8 & $R$ \\
\hline Red-tailed Hawk & + & + & $\mathrm{R}$ \\
\hline Mourning Dove & + & 0.8 & $\mathrm{R}$ \\
\hline Yellow-headed Blackbird & + & + & $\mathrm{R}$ \\
\hline Northern Oriole & + & + & $\mathrm{R}$ \\
\hline Blue Jay & + & + & $\mathrm{R}$ \\
\hline Red-winged Blackbird & + & + & $\mathrm{R}$ \\
\hline Great Horned Owl & + & + & $\mathrm{R}$ \\
\hline
\end{tabular}




\section{Table 3. EFFECT OF AGE OF NEIGHBOURHOOD ON SPECIES RICHNESS AND BIRD ABUNDANCE. $\pm=$ standard deviation.}

\begin{tabular}{||l|c|c|}
\hline \multicolumn{2}{|c|}{ Age of neighbourhood (years) } \\
& $27-41$ & $42-66$ \\
\hline Mean no. of species & $5.0 \pm 1.91$ & $4.9 \pm 2.06$ \\
\hline Range & $0-11$ & $1-13$ \\
\hline Mean no. of individuals & $11.2 \pm 5.93$ & $10.6 \pm 5.56$ \\
\hline Range & $0-34$ & $1-25$ \\
\hline Sample size & 120 & 120 \\
\hline
\end{tabular}

certain vegetation age. In the present case it may be within 27 years, after which these factor numbers level off.

I thank Lynn W. Oliphant, Paul C. James, Andrew Didiuk, and Alan R. Smith for participation in discussions while designing methodology, and Lynn W. Oliphant for making comments on the manuscript. This study was supported by a Natural Sciences and Engineering Research Council of Canada grant to Lynn W. Oliphant and a University of Saskatchewan graduate scholarship to the author.

1. EMLEN, J.T. 1974. An urban bird community in Tucson, Arizona: derivation, structure, regulation. Condor 76:184-197.

2. GRABER, R.R. and J.W. GRABER. 1963. A comparative study of bird populations in Illinois, 1906-1909 and 1956-1958. III. Nat. Hist. Surv. Bull. 28:383-528.

3. HUHTALO, H. 1978. Differential changes in bird community structure with urbanization: a study in central Finland. Ornis Scand. 9:94-100.

4. HUHTALO,H and O. JARVINEN. 1977. Quantitative composition of the urban bird community in Tornio, Northern Finland. Bird Study 24:179185.

5. LANCASTER, R.K. and W.E. REES. 1979. Bird communities and the structure of urban habitats. Can. J. Zool. 57:2358-2368.

6. LUNIAK, M. 1980. Birds of allotment gardens in Warsaw. Acta Ornithol. 17:297-320.

7. MILLS, G.S., J.B. DUNNING, JR. and J.M. BATES. 1989. Effects of urbanization on breeding bird community structure in southwestern desert habitats. Condor 91:416-428.

8. MUNYENYEMBE, F., J. HARRIS, J. HONE, and H. NIX. 1989. Determinants of bird populations in an urban area. Aust. J. Ecol. 14:549-557.

9. ROSENBERG, K.V., S.B. TERRIL and G.H. ROSENBERG. 1987. Value of suburban habitats to desert riparian birds. Wilson Bull. 99:642-654.

10. SODHI, N.S., A. DIDIUK and L.W. OLIPHANT. 1990. Differences in bird abundance in relation to proximity of Merlin nests. Can. J. Zool. 68:852854.

11. TOMIALOJC, L. 1970. Quantitative studies on the synanthropic avifauna of Legnica and its environs. Acta Ornithol. 12:293-392.

12. TWEIT, R.C. and J.C. TWEIT. 1986. Urban development effects on the abundance of some common resident birds of the Tucson area of Arizona. Am. Birds 40:431-436.

13. VALE, T.R. and G.R. VALE. 1976. Suburban bird populations in westcentral California. J. Biogeog. 3:157165.

14. WILLIAMSON, R.D. and R.M. DEGRAAF. 1981. Habitat associations of ten bird species in Washington,D.C. Urban Ecol. 5:125-136.

15. WOOLFENDEN, G.E. and S.A. ROHWER. 1969. Breeding birds in a Florida suburb. Bull. Fla. State Mus. 13:1-83. 